\title{
Debt-driven water privatization: The case of Greece
}

\author{
Maria Pempetzoglou \\ Department of Social Administration and Political Science., emocritus University of Thrace, Greece
}

Zoi Patergiannaki

Department of Social Administration and Political Science

Democritus University of Thrace, Greece

\begin{abstract}
The privatization of water services is a basic conditionality in the structural adjustment programs imposed by international financial institutions, such as the IMF and the World Bank, on indebted countries. In the same sense, the financial assistance that has been offered to Greece from Troika, since the beginning of the financial crisis, in the late 2009 , was accompanied by the commitment, to privatize, among others, the two largest public water companies. The consequences of water privatization policies include increases in prices, poor quality of services, little or no investment, rise of income inequality, high levels of corruption, loss of jobs and deterioration of working conditions. Despite the fact that privatization of water supply companies has been proven to be ineffective in many parts of the world and the tendency towards the remunicipalization of water services that has lately been detected, international financial organizations continue to set water privatization as conditionality. The unconstitutionality of the policy and the strong opposition of citizens and unions to water privatization seem to be inefficient to prevent the Greek government to proceed to the establishment of a public-private partnership in the water supply sector.
\end{abstract}

Keywords: Debt-driven water privatization: The case of Greece

\section{Introduction}

Many countries, especially developing ones, resort to borrowing from international financial institutions, such as the IMF and the World Bank. These organizations provide funds to governments in immediate financial emergencies. In exchange, governments of the borrowing countries are committed to adopting certain policies as a condition for receiving funds. In most occasions the terms of the contracts entail the rule of 'one size fits all' without taking into consideration the different characteristics of each local economy. The imposed policies are influenced by the dominant economic ideology, neoliberalism. The basis of the neoliberal theory is the decrease of government power, the freedom and deregulation of the market and the unquestionable privatization of state property (Askitas, 2016).

One of the most common conditionalities is the privatization of water and sanitation systems. Despite the fact that the management of such bodies by private companies has been proven ineffective in many countries, both developed and developing, and the global trend of water remunicipalization, international financial organizations insist on imposing water privatization as conditionality to borrowing countries. A prime example of such actions is the case of Greece.

Since the beginning of the Greek financial crisis, in the late 2009, Greek governments have signed three memorandums of understanding with 'Troika' (a group of three international institutions consisting of the European Commission, the European Central Bank and the International Monetary Fund) in 2010, 2012 and 2015. Troika's mission was to monitor and assess the countries that were receiving loans from the EU and the IMF. The financial assistance offered was combined with a commitment to implement a strict program of conditionality measures, including the privatization of several state-owned companies. Among others, the privatization list included the two largest public water companies in Greece. This act started an array of reactions both in a national and international level. However, even after the strong opposition against privatization and the public statements of the Greek prime-minister disclaiming any thought of commercialization of water, Greek authorities move forward with the privatization of these companies. 
The purpose of the present study is to analyze the water privatization policy that international financial institutions impose on indebted countries through conditionality, to present the obligations of the Greek state for water privatization under the memorandums and to investigate the privatization attempts of the two largest supply and sewerage companies of Greece, against the European and international trends. In the end, it makes an effort to outline the potential consequences of water services privatization in Greece.

The rest of the paper is organised as follows. Section 2 presents the international organizations pressure for water privatization policy. Section 3 analyses the conditionality in water sector privatization that has been imposed on Greece via the memorandums. Section 4 explores the privatization efforts of the two largest public water companies of Greece, namely the Thessaloniki Water Supply and Sewerage S.A. (EYATH) and the Athens Water Supply and Sewerage S.A. (EYDAP). Section 5 lists the consequences of water services privatization in indebted (and not only) countries and section 6 the potential consequences of water privatization in Greece. Section 7 concludes.

\section{International organizations pressure for water privatization}

Throughout the years, many developing countries, experiencing an economic crisis, call upon international financial institutions to provide them with assistance. The International Monetary Fund (IMF) and the World Bank are the oldest and the most well-known ones. Apart from the aforementioned organisations, other international financial institutions that provide financial aid to developing countries is the African Development Bank, the Asian Development Bank and the InterAmerican Development Bank. Any member state of these organizations may request financial assistance, if it lacks sufficient financing to meet its net international payments. Most of these financial institutions frequently cooperate with each other on many levels to provide assistance to their member countries, conditional upon the adoption of certain policies (Bank Information Centre, 2017).

The IMF and the World Bank provide loans to governments, especially of poor countries, that are unable to obtain funds through the financial markets and they commit governments to implement certain policies as a condition for receiving funds. In particular, IMF resources provide a cushion that eases the adjustment policies and reforms that a country must make to tackle its balance of payments problems, stabilize its economy and help restore conditions for strong sustainable economic growth (IMF, 2016). Following the request, the IMF and the target country configure a lending "arrangement" which may, depending on the lending instrument used, specify the economic policies and measures the country has agreed to implement to resolve its balance of payments problem (IMF, 2017). The so-called structural adjustment programme usually includes measures aiming to improve the functioning of markets and institutions and promotes, for instance, tax and financial sector reforms, privatization of public enterprises etc. The rationale behind the adoption of structural adjustment programmes is to increase export earnings, through which the target country is expected to pay off its debts (The Thistle, 2000). In most cases, the arrangements are detailed in a 'Memorandum of Understanding'.

Within the European Union, the Euro area countries, experiencing severe financing distress can request assistance from the European Stability Mechanism (ESM) (European Commission, 2017). The ESM is an intergovernmental institution which raises its funds from the international capital markets and it grants loans in order to safeguard the financial stability of the Euro area. A precondition for the ESM bailouts is the implementation of a tough macroeconomic adjustment programme, prepared by the European Commission, in cooperation with the European Central Bank and, sometimes, with the participation of the IMF. The conditionality includes reforms that focus on: a) fiscal consolidation, such as reductions in government expenditure and public administration costs and increases in revenues through privatizations or tax reforms, b) structural reforms, aiming to increase employment and improve competitiveness and c) financial sector reforms, in order to strengthen banking supervision or recapitalize banks (ESM, 2017).

Although international financial institutions are seemingly neutral, in fact, they are dominated by the interests of industrialized countries. The voting power of countries is determined by their capital contribution to the institutions as well as other political factors associated with their influence on the world (The Thistle, 2000). Specifically, in IMF, the G7 controls more than $40 \%$ of the votes on the Board of governors, while the US and the European Union together carry more than $55 \%$ of the votes (Bullard, 1999). The rest of the approximately 150 member countries are either under-represented or totally excluded from the decision-making process. In the World Bank, the president traditionally comes from the USA and his choice entails congressional involvement; in the IMF, the managing director is traditionally a European (The Thistle, 2000). 
The policies that the institutions impose on borrowing countries are highly neoliberal; they promote 'labor flexibility', tax increases and social spending cuts (especially in education and health), privatization of public sector enterprises and property (particularly utility and public transport companies) and financial liberalization. The neoliberal conditionality regime leads to deregulation of the economy, deprivation of public sector from its property and dismantling of the welfare state; on the other hand, it highly benefits large trans-national corporations and wealthy investors (The Thistle, 2000). The empirical evidence from the implementation of the neoliberal practices shows that these policies have been devastating for people, infrastructure and the environment.

Since the water supply and sanitation system are under governmental control, in most borrowing countries, the privatization of water utilities is included in the broader set of privatization policies that international financial institutions promote through conditionality. Particularly, in 21 countries, which proceeded to a loan arrangement with the IMF and the World Bank, conditionality included the imposition of water privatization or cost recovery requirements (Alexander et al., 2001). Cost recovery is associated with the elimination of state subsidies that increase budget deficit. Specifically, in developing countries, the justification for water privatization is based on the fact that the economy is too weak to provide subsidization of water and sanitation services. In this case, water consumers should cover the cost of these services. Financial institutions claim that the sale of public enterprises will have beneficial effects not only on the water system administration but also on the country's public debt and budget deficit. Moreover, the resources generated through privatization and cost recovery policies could provide access to water to a higher percentage of the population. However, this is not confirmed by the empirical evidence (Alexander et al., 2001).

Among the countries that were forced to adopt water privatization policies are Ghana, Mali, Mozambique, Tanzania, Argentina, Bolivia, Uruguay, Madhya Pradesh, Indonesia, Angola, Benin, Guinea-Bissau, Honduras, Nicaragua, Niger, Panama, Ruanda, Sao Tome and Principe, Senegal and Yemen (Alexander et al., 2001). The last example, in which the process is not completed yet, is Greece. The consequences from the implementation of these policies are examined in section 5 .

\section{Water sector privatization as conditionality in Greece}

In the aftermath of the global financial crisis of 2007, Greece was confronted with the most severe economic crisis in its post-war history. The Greek sovereign debt crisis began in the late 2009, for reasons that lie beyond the scope of the present study. Greece was shut out from borrowing in the financial markets. The austerity measures that were adopted by the government, such as government expenditures cuts, tax increases, shrinkage of the public sector etc, fell short of their goals. In order to avert bankruptcy - and to avoid spreading crisis to other EU countries too, the Greek government requested and received three bailout loans in 2010, 2012, and 2015 from a triad of organizations, called 'Troika', consisting of the European Commission, the European Central Bank and the International Monetary Fund. The financial assistance offered, was combined with a commitment to implement a strict programme of conditionality measures, which were outlined in three Economic Adjustment Programmes, usually referred to as 'Memoranda of Understanding'. Financial disbursements were conditional on the implementation of austerity measures, budget cuts, structural reforms and privatization of several state-owned companies. Among others, the privatization list included the two largest public water companies in Greece.

In the First 'Memorandum of Understanding', the privatization-related conditionality was directly related to the opening of markets in the transport and energy sectors; indirectly, it was imposed through cuts in expenses of public enterprises and public investment, staff reduction in the public sector and divestment of state assets. The primary aim was the reduction of the fiscal balance from 14\% of GDP in 2009 to below 3\% of GDP in 2014 (European Commission, 2010). This could be achieved through consolidation, based on measures that generate savings in the public sector's expenditures and improve the government's revenue-raising capacity. Specifically, the first adjustment relied on expenditure cuts equivalent to $7 \%$ of GDP. The cuts in public spending aimed at releasing resources to be utilised by the private sector and subsequently at improving competitiveness. The public investment reduction was set at $0.2 \%$ of GDP per year. Among others, the measures included reductions of public employment $(0.3 \%$ and $0.2 \%$ in 2012 and 2013 , respectively) and cut transfers to public entities by $0.4 \%$ in 2012 . On the other hand, tax increases amounted to $4 \%$ of GDP. Furthermore, the first memorandum foresaw the reinforcement of the role of the Hellenic Competition Commission (HCC), since network industries were going to be progressively liberalized, especially in the transport (railway services) and energy sectors. Certain measures to achieve greater transparency, improve financial performance and reduce losses in state enterprises were undertaken. The potential divestment of state assets, including those of land owned by public enterprises or the government, was placed under review. The government was also committed to re-examine the scope of improving corporate governance and 
strengthen the supervision of state-owned assets. The privatization plan for the divestment of state assets and enterprises was intended to accumulate at least $€ 1$ billion, during the time period 2011-2013, by reducing the state intervention in the real economy, improving market efficiency and cutting fiscal contingencies (European Commission, 2010).

In the Second 'Memorandum of Understanding', the expansion of privatization was a harsh conditionality. The privatization programme aimed at raising revenues by $€ 50$ billion in the medium term; privatization receipts should have been $€ 4,500$ million in 2012, $€ 7,500$ million in 2013, $€ 12,200$ million in 2014 and $€ 15,000$ in 2015 (Second Memorandum of Understanding, 2012). The government was pledged to sell all its remaining shares of the state-owned enterprises, if necessary, in order to achieve the goals of privatization. The establishment of the Hellenic Republic Asset Development Fund (HRADF), in 2011, helped to this end. According to Law No. 3986/2011, the object of the Fund is to exploit the private property of the Greek state and the Greek public entities, whose share capital is entirely, directly or indirectly, owned by the Greek state or legal entities. The public control should be limited only in the cases of critical network infrastructure. The revenues from the exploitation of these assets must be exclusively applied for the repayment of the Greek public debt. Moreover, these proceeds would not substitute fiscal consolidation efforts and they would not be counted in the calculation of the annual general government deficit. The second economic adjustment programme committed the government to transfer to the HRADF all assets that were expected to be privatized in 2012 and 2013 and to expedite the privatization process. At that time, much public property, including the Thessaloniki Water and Sewerage Company (40\%) and the Athens Water and Sewerage Company (27.3\%), had been transferred to the Fund with the scope of selling it gradually (European Commission, 2017). The intermediate steps, which had to be made, so as to ensure that privatization would be successful in terms of receipts, were included in the restructuring of loss-making firms, state-aid clearance, rights clearance and regulatory changes, including the unbundling of utilities. The driving force behind this decision was that, by transferring assets in key sectors of the economy to more productive uses through privatization and concessions, would encourage foreign direct investment (FDI) and other private investment, supporting the economic recovery and long-term growth. Given the assets targeted for sale, the government anticipated $€ 50$ billion in proceeds over the lifetime of the asset sale program, including at least $€ 19$ billion through 2015. The steps to move the privatization process forward in 2012 were, for the most part, prominently transferring the asset to the privatization fund and appointing the advisors, restructuring of the asset, filling in public policy and regulatory policy gaps, designing the tender process, receiving approval of European Commission regarding to procurement, competition and state aid, running the tender and obtaining all necessary by-law approvals. Moreover, the programme designated that the HRADF would not be able to transfer assets back to the general government. If the Board of Directors of the HRADF determined that an asset was not able to be sold in its current form, it would be sold in pieces or it would be liquidated. The HRADF was able to raise money, on market terms, but it could not grant liens over any of its assets, if this might have prevented or delayed the relevant assets from being privatized. As far as the Thessaloniki and Athens Water and Sewerage Companies are concerned, regulators and pricing policy were established by June 2012 (European Commission, 2012).

In the Third 'Memorandum of Understanding', among others, the Greek authorities were committed to implement a privatization programme in order to support investment. The conditionalities included the establishment of an independent Fund, known as 'Super Fund', targeted to privatize independently evaluated Greek state assets (Law No. 4389/2016, Article 197). The Super Fund was a private development company which would operate for the public good, by applying rules of the private sector (Law No. 4389/2016). The overarching objective of the Super Fund was to manage valuable Greek assets, which would be utilised to the maximum, based on the guidelines of the Organisation for Economic Co-operation and Development (OECD). Its goal was to protect, create and, ultimately, maximize their value which would be monetized through privatizations and other means. The methods of property utilization consist of the privatization through sale, the transfer of any property or personal rights, the leasing of assets, the concession of the right of use or exploitation, the conferral of management and the restructuring of businesses and real estate. Public enterprises monitored by the Super Fund would: a) be subject to the appropriate supervision in accordance with the laws of the state and the EU, b) implement and support the government's policies and c) undertake the provision of 'Services of General Economic Interest' (SGEI) (Law No. 4389/2016). The Super Fund was planned to be managed by the Greek authorities and supervised by relevant EU institutions. Its management would be comprised by three members appointed by the government and two representatives of the creditors with the right of veto (Hellenic Corporation of Assets and Participations, 2017). The revenues from the privatization programme would be used to repay the recapitalisation of banks and other assets, to decrease the debt to GDP ratio and to conduct investments (Euro Summit, 2015). As far as the water policy was concerned, the agreement foresaw the establishment of a stable regulatory regime as a key to propel investment in the water networks 
and to protect consumers in terms of pricing policies (European Commission, 2015). The government was obliged to take all necessary actions to fully implement the regulatory framework for water utilities, based on the methodology completed by the Special Secretariat of Water in 2014. The EU would provide technical assistance. The programme also aimed to further enhance and strengthen the water regulator, in order to enable it to take independent regulatory decisions. The privatization method of the Thessaloniki Water and Sewerage Company included the sale of $23 \%$ of share capital; HRADF would preserve $74 \%$ of the shares. In the case of the Athens Water and Sewerage Company, the privatization method included the sale of $11 \%$ of the shares, whereas HRADF would maintain $27 \%$ of the shares (European Commission, 2015).

\section{Privatization attempts of public water companies in Greece}

\subsection{Thessaloniki Water Supply and Sewerage S.A. (EYATH)}

The Thessaloniki Water Supply and Sewerage Co. S.A., trading as EYATH S.A., was founded in 1998 by Law 2651/3.11.1998 and resulted from the merger of the Thessaloniki Water Supply Organization S.A. (OYTH S.A.) and the Thessaloniki Sewerage Organization S.A. (OATH S.A.). OYTH and OATH, which had been bodies governed by public law, had been converted into Sociétés Anonymes on 25.6.1997. The company is supervised by the Ministry of Economy and Finance and the Ministry of Macedonia-Thrace, and its effective term is 99 years, running from 3.11.1998 to 3.11.2097. In the early 2000s, the Interministerial Commission for Privatizations decided to sell off the shares from the share capital increase and the existing shares owned by the Greek State - which had been its exclusive shareholder up to that point. In 2001, EYATH's extraordinary general meeting of shareholders unanimously decided to increase the share capital and list the company's shares on the Main Market of Athens Stock Exchange (ATHEX) (EYATH, 2017). The same year, a thirtyyear contract was signed in Thessaloniki that granted to the municipal company Thessaloniki Water Supply and Sewerage CO. S.A. (EYATH) the exclusive right to provide water (EYATH, 2017).

In 2012, the transition of public assets into the Hellenic Republic Asset Development Fund (HRADF) was decided. Thus, in 2014 , the company stocks were sold partly to the private sector (74\% of the share capital is held by HRADF, $5 \%$ by the French company Suez, while the remainder are free trading in the Athens Stock Exchange (Asset Development Fund, 2017). However, in 2013, the representative of HRADF announced the sale of $51 \%$ of shares of EYATH (Save Greek Water, 2013). After the announcement, a competition was proclaimed for the auction of EYATH and the most prominent interested companies were the Israeli water company Mekorot and SUEZ (which already owned $5 \%$ of the shares). These firms would take over the company's management, in association with the Greek construction firm EllAktor (Petitjean, 2014). Since then, many actions and campaigns occurred in Thessaloniki, aiming to block further privatization of EYATH. Resolutions and demonstrations have been the main tools for citizens to press the government to keep water in public hands. The most significant actions are the 'SOSTE to NERO' coalition and the 'Initiative 136' movement. The 'SOSTE to NERO' coalition was created by unions and has managed to get the support of both local and international forces to its purpose (Petitjean, 2014). The 'Initiative 136' was also created by a group of citizens and unions; its goal was the transformation of EYATH into a cooperative ownership, with the owners being its 'customers', the citizens of Thessaloniki. The concept behind this coalition was that every citizen would buy a non-transferrable share of the company, which was valued at $€ 136$ per household. In order to accomplish its goal, the movement 'Initiative 136' called for international assistance from 'ethical investors' and social finance organizations, in order to help takeover EYATH. However, 'Initiative 136' ended in an unfortunate way, when its proposition was not accepted by the HRADF (Petitjean, 2014). Noteworthy is that, on $18^{\text {th }}$ May 2014, during an informal but well-organised referendum that was held in Thessaloniki, $98.3 \%$ of the citizens voted against water privatization. In the case of EYATH, the term of preserving $50 \%$ plus one share of EYATH by the state, was imposed by the Hellenic Council of State; thus, only a minority stake could be sold to the private sector (Council of State decision No 1906/2014). The ratio between the sale price of EYATH and its financial results are similar: about $€ 110$ million for a 51\% stake, whereas the business posted a net income of $€ 18$ million in 2013, a turnover of $€ 77$ million, with $€ 33$ million cash reserves and $€ 135$ million equity (Petitjean, 2014). According to the decision, the next steps adopted by the Government are as follows: 1) selection of consultants from HRADF until the third quarter of 2016, 2) evaluation of alternative options for the sale of $23 \%$ of shares, 3) business plan creation and accomplishment, and 4) improving the regulatory framework and adoption of the revised Concession from the Company and the Hellenic government (Asset Development Fund, 2016).

In a Press Conference, on $9^{\text {th }}$ September 2016, the Greek Prime Minister stated: 'The public form of water is established. The government tries to increase the revenues and the competitiveness of the company under the governmental control. In this time of free economy and market, it is clear that the governmental control can be ensured by the majority of the 
company's shares. The involvement of key investors holding the marginal of shares will enhance the competitiveness of the company. The government will not sell the majority of the shares, water is a public good. Nevertheless, EYDAP and EYATH are part of the market economy, so the government has to be more flexible in its decisions' (Limperis, 2016). However, the decision of the Parliament, taken on $27^{\text {th }}$ September 2016, granted the share capital of EYATH that belonged to the state to the Super Fund. People reacted intensely to the undemocratic decision. Water companies' employees went on strike, cutting off even the water supply at the offices of the ruling party (SYRIZA) in Thessaloniki. The case is still in progress, as the actions of citizens, stakeholders and NGOs against the inclusion of water companies in the Super Fund will continue, until it is ensured that these policies will not be implemented.

\subsection{Athens Water Supply and Sewerage S.A. (EYDAP)}

The municipal Athens Water Supply and Sewerage Company (EYDAP S.A.) is the largest water supply company in Greece with $9,500 \mathrm{~km}$ of pipeline length. It provides water services to approximately $4,300,000$ customers and sewerage services to 3,500,000 residents in the greater Athens and Piraeus area. The company was founded in 1980 after the merge of the 'Hellenic Water Company' (EEY S.A.) and the 'Greater Athens Sewerage Organization' (OAP S.A.). In 1999, EYDAP took its present legal form, as all of its major assets were transferred to the company 'EYDAP Assets' and remained state property. The same year, EYDAP signed a twenty-year contract, stating that the company would undertake the exclusive provision of water services. In January 2000, it was listed on the Main Market of the Athens Stock Exchange (EYDAP, 2017).

In 2012, according to the common ministerial decision 206/25.4.2012, 34,033\% shares of EYDAP, which was under the governmental ownership, was decided to be transferred to HRADF (SEKES, 2012). However, this action was not completed, because the EYDAP union requested the cancelation of the decision. This request has been accepted from the Hellenic Council of State and the conflict between civil society and private companies was finally resolved in 2014 after the Hellenic Council of State decision to block any further privatization of these companies for the sake of public health. The fact that the company did not pass entirely into private hands is due to the Greek citizens uprising and the resistance shown by European and international movements. Furthermore, the Court set the condition that the Greek state would maintain at least $50 \%$ plus one share, on the grounds that the right of citizens to water access is above any private initiative aiming to make profit through this procedure. In 2014 , the company was partially privatized (the Greek state holds $34.03 \%$, the HRADF 27.30\%, investor John Paulson 9.99\%, and the remainder is in free float in the stock market (Asset Development Fund, 2016). HRADF's $61 \%$ stake in EYDAP could be sold for $€ 350$ million, which compares well to a net annual profit of $€ 62$ million out of a €353 million turnover in 2012, €43 million cash reserves, €881 million equity and €1.2 billion owed to the company by the Greek government and various agencies and businesses (Petitjean, 2014). In 2015, the topic of water companies' privatization reappeared on the government's agenda, as a result of the agreement on prerequisites for loan performance between the Greek government and its creditors. Despite the success of the Pan-European initiative 'Right2water' to gather 32,000 signatures against the commercialization of water (Save Greek Water, 2016), on 27 September 2016, the Greek Parliament voted a law on the integration of EYDAP in the Super Fund. Judging from the purpose of the Super Fund and the way it operates, it seems that the aim of water companies will not be to ensure water quality and sewage treatment as a social good. After this blatant violation of access to water as an inalienable human right, over 3 million messages were sent to the members of the Parliament who stood against these measures (Save Greek Water, 2016).

\section{Consequences of water services privatization in indebted (and not only) countries}

The global experience of privatization programs in water and sanitation services indicates that the private sector could not achieve the desired results. The privatization of water has led to several problems, mostly associated with increases in water tariffs, reduction in water quality, health problems, limited use of water supply, corruption and increases in government spending. Despite the catastrophic consequences for both the state and the citizens, lenders insist on keeping privatization of water services as a requirement in adjustment programmes. Below are listed examples of indebted countries with IMF/World Bank-imposed water privatization programmes.

In Ghana, the fault lied in the very first stage of the contract, which was very general and lenient toward the obligations of Aqua Vitens Rand Limited (AVRL). Specifically, AVRL invested nothing in the already poor state of the Ghana Water Company (GWC); noteworthy is that the state of the company was the reason for its privatization. Having failed to fulfil the arrangement to the end and by spreading falsehoods about the efficiency of their company, AVRL did not manage to reduce 
non-revenue water and improve water quality. Due to the consistently poor performance in six other target areas, the contract was rendered null and void (Remunicipalization tracker, 2017).

Another example is that of Maputo in Mozambique, where a 15-year contract ended prematurely in 2010, when the government bought back $73 \%$ of the water supply from the holding company, Fundo de investimento e Património do Abastecimento de Água (FIPAG). The partnership did not meet the contractual targets and obligations, since, after increasing water supplies, the volume of non-revenue water did not have the same outcome (Remunicipalization tracker, 2017).

In Tanzania, CWS company entered into a problematic contract with DAWASA, in 2003. Five months later, CWS stopped paying its monthly lease fee, resulting in a drop in the company's revenue by a third. This was due to the fact that new costumers did not register in the billing system, while the existing ones benefited from increased flexibility in making payments directly to the company's revenue collectors. After that, the government decided to terminate the contract prematurely (Remunicipalization tracker, 2017).

In Argentina, the contract was based on neoliberal recommendations and was considered as a flagship of privatization, worthy of replication by other countries. However, the private operator failed to comply with its contractual obligations and followed a strategy with the sole purpose of extraordinary profits, but Argentinean authorities turned a blind eye. This strategy was successful during the period of forced stability of the Argentinean currency (1993-2001), but imploded prematurely with the collapse of the neoliberal model in 2002 (Remunicipalization tracker, 2017).

In Uruguay, Obras Sanitarias Del Estado (OSE), the national public body who served as the provider of drink and wastewater services for the whole country and the private company URAGUA, who were tasked with the provision of water, had reportedly broken contractual obligations to renew and expand the water network. They also charged excessive service rates and connection fees that wide sectors of society could not afford. Services were of poor quality and even some public taps were disconnected (Remunicipalization tracker, 2017).

Noteworthy is that the negative results of water privatization are not limited to developing indebted countries that were forced to implement privatization policies, but also to developed countries that decided to privatize their water service companies for political and economic reasons. Various studies show that private water companies have been less efficient than the public sector even though they had access to better technology (Saal et al., 2007), they have caused environmental problems, they tend to overcharge their customers or raise the prices of household bills in order to open new sewerage facilities. According to a World Bank study, the increases in productivity that have been observed, with a simultaneous reduction in staff did not lead to a reduction in prices (Gassner et al., 2009). In most countries, private water companies invest less than the public enterprises for the maintenance and upgrading of the network (Castro and Heller, 2009); it is assumed, that in order for entrepreneurs to decide to invest, they expect that their investment will secure them a greater profit than the original cost, which in water services is not feasible (EPSU, 2012). It seems that, in all cases, water supply constituted a monopoly of certain companies, while in most cases no contest for the assignment of the project had taken place. The cases of Paris, Jakarta and Buenos Aires confirm the desire of companies to engage in joint ventures rather than compete with each other. Furthermore, in France and Italy some private companies have been convicted by the Commission for Protection of Competition for non-competitive behavior (EPSU, 2012). There have been several cases of deception of the public from private bodies trying to ensure a long-term profitable contract, at the public's expense. In several occasions, the companies Suez and Veolia have been accused of public officials' corruption, illegal contribution policy, bribe, price fixing, cartels' management and fraudulent accounting, such as in the case of Buenos Aires, France, Italy and the USA. According to a report from the Cour des Comptes (1997) - the National audit body in France, the system of privatization on which Suez and Veolia built their sovereignty, was routinely faulty: 'The lack of supervision and control from public services was aggravated by the lack of transparency of this form of management, and has led to abuses' (EPSU, 2012). In most cases, the terms of contracts, between the private and public sector, are confidential documents; hence, public accountability is impossible. In others, such as that of Buenos Aires, the terms of contracts were renegotiated repeatedly, with the purpose of ensuring more privileges and benefits to private companies at the consumers' expense. Another case is that of Berlin, where the Public Private Partnership (PPP) concession contract was kept secret and included a written guarantee of great profit. In 2012, the Federal Cartel Office ruled that the agreement violates German law on competition; therefore, the company was forced to reduce prices by $19 \%$ (EPSU, 2012). Thus, in many cases, the continuous growth in fees was not arbitrary, but the result of these negotiations. One of the main arguments for the transitioning from public to private sector is the earnings expected to be raised through the sale of the water company. 
However, in fact, governments earn far less than the real value of these firms, especially in cases where the buyers know that the government is forced to sell the company, which appears to be a common phenomenon in countries where financial institutions are involved. In some cases, in which the purchases made at the state's desired price, the cost can possibly be transferred to consumers through raising prices. For instance, in France, private companies paid millions to obtain the water supply license; after completion of the transaction, the companies added an "entrance fee" on consumers' bill. Thus, the profits of the public sector were made at the expense of the consumers (Hall and Lobina, 2001). As a result, the countries are more likely to lose money even after selling part of their property, significantly decreasing their profits and rendering them unable to pay off their long term debts (EPSU, 2012).

\section{Potential consequences of water services privatization in Greece}

Taking into consideration the aforementioned examples, the consequences of water privatization in Greece are not expected to differ. First of all, since the beginning of the financial crisis, in Greece, the market value of public companies, and generally of all the public and private sector assets, has decreased substantially and it has fallen below the objective value. As a consequence, the revenues from the privatization of water companies will fall short of the ones that could be obtained in the pre-crisis period and they will not be able to cover a significant part of public debt. Moreover, potential buyers will try to downgrade even more the value of the companies, since they are aware that the Greek authorities are obliged to sell them. The selling price of the companies is not expected to increase through tendering, since the international experience has shown that international water companies prefer to engage in joint ventures rather than compete with each other. Even if the authorities put pressure for selling the companies at a certain price, it cannot be ensured that these costs will not be passed on to the consumers after the takeover of the company by the private sector. Ultimately, the water service companies are profitable and their sale will result in a loss of revenue for the government and difficulties in repaying public debt.

After privatization, the natural water monopoly that will be created, will allow private companies to demand monopoly prices, which will be substantially higher than the prices under perfect competition. Furthermore, the private sector's priority to make large profits goes hand in hand with price increases. This notion of private companies may have destructive ramifications on poor households, which do not have the ability to cope with high water prices compared to wealthier households (Tilch and Schmitz, 2013). Specifically, in Greece, the rise in water prices in combination with the economic crisis will increase the number of people who will lose their human right to have access to water and sanitation, as this was established by the United Nations on 3/8/2010 (A/RES/64/292) (UN, 2010). Global experience has shown that privatization does not bring in new investments. On the other hand, in cases where new investments were carried out, this entailed a dramatic increase in tariffs. Private companies will try to raise their profits by laying off the companies employees; immediately after the privatization, they will recruit them - since they have the necessary knowledge and skills, but with more flexible working conditions (Kallis, 2014). The customers should also be concerned about the quality of water that private companies provide, since the deterioration of water quality is an additional method private companies apply to restrict their operational costs. Moreover, the lack of financial motives and the weak supervision may lead to the indifference of the companies about the size of potential problems that customers may face (Tilch and Schmitz, 2013). The privatization of the country's largest water companies, EYATH and EYDAP, involves the risk of losing control on the decision making, regarding the country's water policies and planning. Private companies would be reluctant to promote water saving, since this would induce a decrease in sales (Kallis, 2014). Given the weak regulatory framework in Greece and the high rate of corruption, it is unlikely that the water privatization will ensure benefits for both the state and the people. Finally, the sale of these companies would result in a scandalous violation of the democratically expressed will of the Greek people, as it has been recorded at the Thessaloniki referendum on the 18th of May 2014 (Save Greek Water, 2016). After all, the negative effects of water privatization have already been noted by our European partner countries and lenders, which have turned to the remunicipalization of their water companies.

\section{Conclusions}

This paper examines the discursive strategy for water privatization that international financial institutions, such as the IMF and the World Bank, impose on indebted countries through conditionality. Evidence from water privatization projects around the world reveals increases in water prices, degradation of water quality, restrictions in water access. People of indebted countries often face the tragic trade-off dilemma between food, water, health and schooling (Alexander et al., 2001). Regardless of the devastating results of water privatization at both the social, economic and environmental level, 
international financial institutions insist to turn a blind eye on such examples and continue to pursue a global privatization plan.

In Greece, the financial assistance offered, was combined with a commitment to implement a strict program of conditionality measures, which included the privatization of the two largest water and sewerage state companies. Despite the global trend of water remunicipalization, 'Troika' puts pressure on the Greek government to establish a public-private partnership in the water supply sector. Even after the strong opposition of citizens and unions and the State Council's decision, the privatization of water services remains a conditionality. Any attempts on privatizing water supply and sewerage in Athens and Thessaloniki is expected to have similar social and economic consequences to other indebted countries.

\section{References}

[1] Askitas, A., 2016. What is the neoliberalism? [Online]. Available at: http://www.newsfish.gr/ [accessed 20/11/2016]

[2] Alexander, N., Grusky, S. \& Dossani, S., 2001. IMF and World Bank Push Water Privatization and Full Recovery on Poor Countries, News and notices for IMF and World Bank watchers, [Online]. 2 (4), Available at: https://www.academia.edu/14256584/News_and_Notices_Vol._2_No._4_Spring_2001_[accessed: 20/4/2017]

[3] Asset Development Fund, 2016. Business development program, The Official Gazette of the Hellenic Republic (National Printing Office), Anderson Leal 2001. Free market environmentalism. New York: Palgrave

[4] Bank Information Center, 2017. Why are international financial institutions important? International Financial Institutions, [Online]. Available at: http://www.bankinformationcenter.org/resources/institutions [accessed: 3/4/2017]

[5] Bullard, N., 1999. G7 strengthens its grip on global economy. Focus on the Global South, [Online]. Available at: https://focusweb.org/node/202 [accessed: 10/4/2017]

[6] Castro, J., E. \& Heller, L., 2009. Water and Sanitation Services: Public Policy and Management. London: Earthscan.

[7] Common Ministerial Decision 206/25.4.2012

[8] Council of State decision No 1906/2014, [Online], Available at: http://www.dsanet.gr/Epikairothta/Nomologia/ste\%201906_2014.htm [accessed 12/12/2016]

[9] ESM, 2017. [Online], Available at: https://www.esm.europa.eu/about-us [accessed: 10/4/2017].

[10] European Commission, 2010. The Economic Adjustment Programme for Greece. European Economy, Occasional Papers 61, [Online], Available at:

http://ec.europa.eu/economy_finance/publications/occasional_paper/2010/pdf/ocp61_en.pdf [accessed: 3/4/2017].

[11] European Commission, 2015. Memorandum of Understanding 2015, Financial Assistant to Greece, European Economy, [Online], Available at: https://ec.europa.eu/info/sites/info/files/01_mou_20150811_en1.pdf [accessed: 3/4/2017]

[12] European Commission, 2017. EU Financial Assistance, [Online], Available at: https://ec.europa.eu/info/business-economy-euro/economic-and-fiscal-policy-coordination/eu-financialassistance_en [accessed: 2/4/2017]

[13] European Public Service Union - EPSU, 2012. Why water is a public service: exposing the myths of privatization. London: Public Services International Research Unit (PSIRU).

[14] Euro Summit, 2015. Euro Summit statement of 12 July 2015, SN 4070/15,[Online], Available at: http://www.consilium.europa.eu/en/policies/financial-assistance-eurozone-members/greece-programme [accessed: 4/4/2017].

[15] EYATH, 2017. The Company, [Online], Available at: http://eyath.gr/swift.jsp?CMCCode=060101\&extLang=LG [accessed: 3/4/2017]

[16] EYDAP, 2017. The Company, [Online], Available at: https://www.eydap.gr/TheCompany/CompanyProfile/ [accessed: 3/4/2017]

[17] Gassner K., Popov, A. \& Pushak, N., 2009. Does private sector participation improve performance in electricity and water distribution? PPIAF Trends and policy options, No. 6, [Online], Available at: http://www.worldbank.org [accessed: 10/1/2017]

[18] Cour des Comptes, 1997. La gestion des services publics locaux d'eau et d'assainissement, 
[19] [Online], Available at:

https://www.google.gr/url?sa=t\&rct=j\&q=\&esrc=s\&source=web\&cd=2\&cad=rja\&uact=8\&ved=0ahUKEwj2puOy7HTAhWIfFAKHc6hBssQFggoMAE\&url=https $\% 3 \mathrm{~A} \% 2 \mathrm{~F} \% 2 \mathrm{Fwww} . \mathrm{ccomptes}$.fr $\% 2 \mathrm{~F}$ content $\% 2 \mathrm{Fdownload} \% 2 \mathrm{~F}$ 2841\%2F28632\%2Ffile\%2FGestion-des-services-publics-eau-etassainissement.pdf\&usg=AFQjCNF1bG371Kk2jY1myh78Et6coXnGnA [accessed: 20/4/2017]

[20] Hall, D. \& Lobina, E., 2001. Private to Public: International lessons of water remunicipalization in Grenoble, France. London: Public Services International Research Unit, University of Greenwich, [Online], Available at: http://www.epoc.uni-bremen.de/publications/pup2001/files2001/Hall_Grenoble.PDF [accessed: 10/3/2017]

[21] Hellenic Corporation of Assets and Participations, 2017. [Online], Available at: http://www.hcap.gr/?q=en/content/mission-vision [accessed: 19/4/2017].

[22] IMF, 2016. IMF Lending, IMF Factsheet, [Online], Available at: http://www.imf.org/About/Factsheets/IMFLending?pdf=1 [accessed: 9/4/2017].

[23] IMF, 2017. Lending by the IMF, [Online], Available at: https://www.imf.org/external/about/lending.htm [accessed: 9/4/2017].

[24] Kallis, G., 2014. 'Water is everyone's business.' There are alternatives to privatization. (in Greek), Kinissi 136, [Online], Available at: http://www.136.gr [accessed: 19/4/2017].

[25] Law No. 2651/1998, Government Gazette 248/A/3.11.1998

[26] Law No. 3986/2011, Government Gazette 152/1.7.2011

[27] Law No. 4389/2016, Government Gazette 94/27.5.2016

[28] Limperis, K., 2016. The declaration on water, which the Prime Minister did not do, and the statement he finally

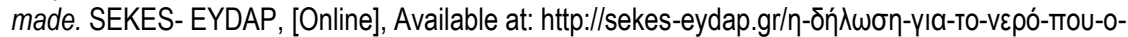
пршөUтाoupyós [accessed: 3/4/2017].

[29] Petitjean, O., 2014. Forced Privatizations in Greece: Suez Eyes Taking Over the Water Services of Athens and Thessaloniki, Multinationals observatory, [Online], Available at: http://multinationales.org/ForcedPrivatizations-in-Greece [accessed: 3/4/2017].

[30] Remunicipalization Tracker, 2017. [Online], Available at: http://www.remunicipalization.org [accessed: 3/4/2017].

[31] Saal D., Parker D. \& Weyman-Jones, T., 2007. Determining the contribution of technical change, efficiency change and scale change to productivity growth in the privatized English and Welsh water and sewerage industry: 1985-2000. Journal of Productivity Analysis, 28 (1).

[32] Save Greek Water, 2016. How the new Greek Super-Fund affects water services, [Online], Available at: http://www.savegreekwater.org/archives/4582 [accessed: 3/4/2017].

[33] Second Memorandum of Understanding, 2012. Memorandum of Understanding on Specific Economic Policy Conditionality.

[34] SEKES, 2012. Action against HRADF by EYDAP employees. [Online], Available at:

[35] http://sekes-eydap.gr/ [accessed: 9/4/2017].

[36] The Thistle, 2000. The IMF and the WORLD BANK: Puppets of the Neoliberal Onslaught, 13 (2), [Online], Available at: http://www.mit.edu/ thistle/v13/2/imf.html] [accessed: 10/4/2017].

[37] Tilch, R. \& Schmitz, K., 2013. EU's water privatization plans - Benefits and downsides of privatizing a public good, Maastricht University, [Online], Available at: http:/lagriwaterpedia.info/wiki/EU\%27s water privatization plans \%E2\%80\%93 Benefits and downsides of privatizing_a_public_good [accessed: 2/4/2017].

[38] United Nations, 3/8/2010 (A/RES/64/292). Resolution adopted by the General Assembly on 28 July 2010, 64/292. The human right to water and sanitation. Sixty-fourth, session Agenda item 48. 